\title{
RESEARCH ON USING MINERAL SORBENTS FOR A SORPTION PROCESS IN THE ENVIRONMENT CONTAMINATED WITH PETROLEUM SUBSTANCES
}

\author{
Piotr Marek PIJAROWSKI ${ }^{1}$, Wilhelm Jan TIC \\ Opole University of Technology, \\ Faculty of Mechanical Engineering, Opole, Poland
}

\begin{abstract}
A research on diatomite sorbents was carried out to investigate their ability to remove hazardous substances from oil spillages. We used two types of sorbents available on the market with differences in material density and particles size of composition. As sorbents we used Ekoterm oil and unleaded petrol 95 coming from refinery PKN Orlen S.A. Two types of sorbents with similar chemical composition but different granulometric composition were used. They are marked as D1 and C1 samples. The fastest absorbent was $\mathrm{C} 1$, but D1 sample was the most absorptive.
\end{abstract}

Keywords: sorbents, mineral sorbents, petroleum substances, sorption of chemical and ecological rescue

\section{INTRODUCTION}

In recent years, environmental protection and industrial pollution have become a number one issue. Poland as a member of the European Union must ratify international agreements in the field of environmental protection, particularly in the field of global warming and degradation of the natural environment. These facts force us to face a difficult task of establishing ways of preventing these processes. The main threat the environment and the humans are exposed to is pollution by petroleum substances. Danger is caused either by processing crude oil or exploiting or extracting oil, which chemically and physically is a toxic

\footnotetext{
${ }^{1}$ Opole University of Technology, Faculty of Mechanical Engineering, St. Mikołajczyka 5, 45-271 Opole, Poland; e-mail:p.pijarowski@ doktorant.po.edu.pl, tel.+48774498390
} 
substance. A number of scientific researches are devoted to studying its production process, transport, convert and storage. Risks of pollution related to oil use are huge as faults occur frequently. It is absolutely necessary to discover a new, alternative source of energy which will be more environmentally friendly. However, alternative sources haven't been adopted by the global market and still processed oil substances remain a major source of car fuel and heating energy. They create a direct danger during production process, transport, conversion and storage. Accidents occur infrequently, but the consequences are devastating. Thus they must be considered as the accidents with high risk rate. Most of the dangerous accidents take place during transportation. Emergency situations can also take place on oil rigs, although it is terare. It is worth emphasizing that considering the volume of produced medium, this can have catastrophic character. First minutes after contamination are most important and that is why time of reaction is very important in this kind of situations. The quick action has to be taken to isolate substances from environment [1].

Rescue teams use specialistic equipments such as peristaltic pump, barrel pump, membrane pump, oil barrier, oil separator etc. for quick collection of the substance. These devices have an adequate chemical resistance and are useful for the areas where the accumulated amount of the substance is large [2].

However, the problem make cases, when a liquid substance is not possible to be recovered by mechanical equipment for many reasons. In order to reduce the effects of either great disaster or small leakage, in the last stage of cleaning of the ground a porous sorbents or dispersants are applied [2].

These sorbents are solid materials (in the form of granular, mats, cushion, sorption barrier, etc.) used to reduce the migration of the substances horizontally and vertically. The most frequently used sorbents are the sorbents of the mineral origin. Because of the specific structure and absorption properties sorbents seems to be very effective [3].

Poland is a country rich in natural mineral sources. In general, they are clayey rocks, siliceous and others, which after slight modification are ideal for sorption processes. They have a wide range of application in industry, agriculture and environmental protection, what shows their versatility. In terms of the sorption properties special interest deserves a group of silicate minerals such as $\mathrm{SiO}_{2}$ diatomite, diatomaceous ground and silica. Their geological composition includes mainly chalcedon and opal, as well as other minerals such as: quartz, stobalit, clay minerals and carbonates. Opal is commonly used as a sorbent material. It is an amorphous mineral consisting of $\left[\mathrm{SiO}_{4}\right]^{-4}$ anions in tetrahedral arrangement, creating a skeleton containing water molecules. Moisture content can be controlled during the drying process. In normal conditions, it may crystallize. These crystals are called chalcedony - a semi-crystallized form variety of quartz [4]. The properties of this type of sorbents are result of 
improved active surface area, porosity and presence of hydroxyl group - $\mathrm{OH}$, sometimes also called silanol. This group is created either in the process of condensation of monomers during the opal synthesis or when monomers are in contact with other substances [4]. "Geological form of diatom is called diatomite (diatomaceous earth filter or slates) $1 \mathrm{~cm}^{3}$ contain around 2,5 billions of diatoms", and the eldest are dated for 400 million years ago" (Fig. 1) [5].

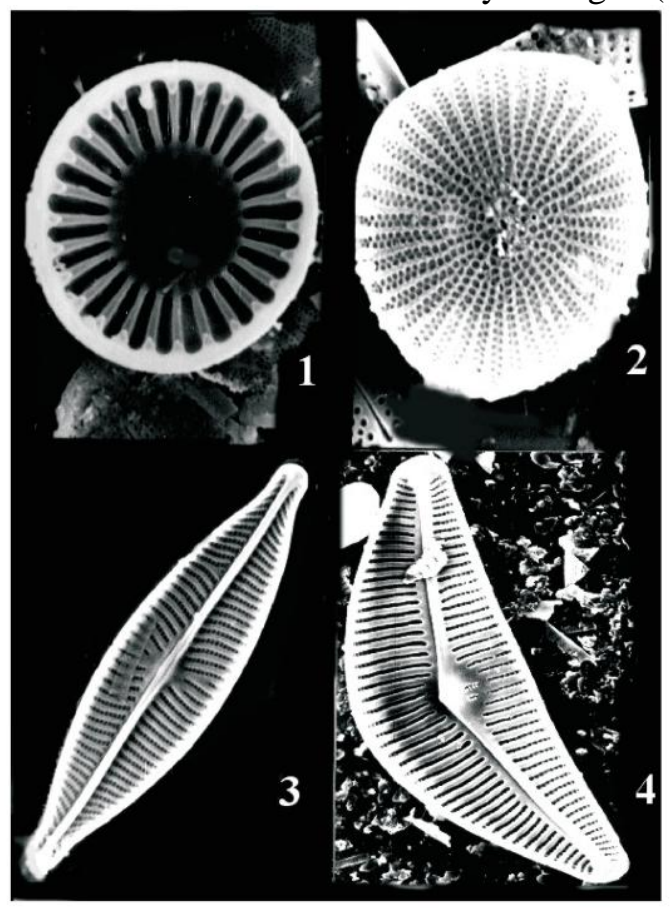

Fig. 1. Diatomite in electron microscope: 1 - Cyclotella meneghinina zoom 6000x, 2 - Stephanodiscus hantzschii zoom 9400x, 3 - Navicula rynchotella zoom 4400x, 4 - Cymbella cistula zoom 3000 [3].

Chemical composition of debris is presented in Table 1.

Table 1. The percentage of substances in contaminated diatomite [2]

\begin{tabular}{|c|c|c|}
\hline No. & Substance & Content [\%] \\
\hline 1. & $\mathrm{SiO}_{2}$ & $65-80$ \\
\hline 2. & $\mathrm{Al}_{2} \mathrm{O}_{3}$ & $5-10$ \\
\hline 3. & $\mathrm{Fe}_{2} \mathrm{O}_{3}$ & $0.5-4$ \\
\hline
\end{tabular}

Diatomite activation with base or acid and base causes an improvement in adsorption ability. This effect can be reached as well with thermal treatment, but performed in relatively low temperatures $\left(150-400^{\circ} \mathrm{C}\right)$. High temperature causes an opposite effect [4]. 


\section{RESEARCH}

\subsection{The physic-chemical properties of sorbents and sorbants used in this research}

We used diatomite coming from two commercial sources (D1 and C2). The physic-chemical properties are shown in table 2.

Table 2. Comparative characteristics of sorbents

\begin{tabular}{|c|c|c|c|}
\hline No. & & Sorbent D1 & Sorbent C2 \\
\hline 1. & \multicolumn{3}{|c|}{ Identification } \\
\hline & & Granulated and calcined & $\begin{array}{l}\text { Granulated and calcined } \\
\text { diatomaceous soil }\end{array}$ \\
\hline 2. & \multicolumn{3}{|c|}{ Chemical composition } \\
\hline & $\mathrm{SiO}_{2}$ & $75.00 \%$ & $75.00 \%$ \\
\hline & $\mathrm{Al}_{2} \mathrm{O}_{3}$ & $10.00 \%$ & $10.00 \%$ \\
\hline & $\mathrm{Fe}_{2} \mathrm{O}_{3}$ & $7.00 \%$ & $7.00 \%$ \\
\hline & $\mathrm{TiO}_{2}$ & $1.00 \%$ & $1.00 \%$ \\
\hline & $\mathrm{MgO}$ & $2.00 \%$ & $2.00 \%$ \\
\hline & $\mathrm{CaO}$ & $1.00 \%$ & $1.00 \%$ \\
\hline & $\mathrm{K}_{2} \mathrm{O}+\mathrm{Na}_{2} \mathrm{O}$ & $2.00 \%$ & $2.00 \%$ \\
\hline 3. & \multicolumn{3}{|c|}{ Form } \\
\hline & & $\begin{array}{c}\text { Granulate } \\
0.5-2.00[\mathrm{~mm}]\end{array}$ & $\begin{array}{c}\text { Granulate } \\
0.3-0.7[\mathrm{~mm}]\end{array}$ \\
\hline 4. & \multicolumn{3}{|c|}{$\mathrm{pH}$} \\
\hline & & 5,5 & 5,5 \\
\hline 5. & \multicolumn{3}{|c|}{ Density } \\
\hline & & $509.00\left[\mathrm{~g} / \mathrm{dm}^{3}\right]$ & $532.00\left[\mathrm{~g} / \mathrm{dm}^{3}\right]$ \\
\hline 6. & \multicolumn{3}{|c|}{ Colour } \\
\hline & & Red - brown & Brown \\
\hline
\end{tabular}

The highest percent have the particles with the diameter of $1,2 \mathrm{~mm}$ and next come those having the size of $2.00 \mathrm{~mm}$ and $0.6 \mathrm{~mm}$. For sample $\mathrm{C} 2$ these data hasn't been provided. Difference can be observed in the colour of the samples. C2 has metallic shinning of small particles.

As a sorbates we used unleaded petrol 95octane and Ekoterm Plus heating oil, which is similar in properties to fuel oil. Both are provided from refinery PKN Orlen S.A., reason for choosing this substance is that they are often involved in accidents causing danger for environment. Characterization of unleaded petrol 95 octane and Ekoterm Plus oil is presented in table 3 and 4 [8], [9]. 
Table 3. Chemical and physical data of heating oil and unleaded petrol 95.

\begin{tabular}{|c|c|c|}
\hline \multicolumn{3}{|c|}{ Ekoterm Plus } \\
\hline No. & Data & Number \\
\hline 1. & Appearance & Red liquid \\
\hline 2. & Smell & Characteristic of diesel and heating fuel \\
\hline 3. & The $\mathrm{pH}$ value & not relevant \\
\hline 4. & Melting and boiling range & $180^{\circ} \mathrm{C}-360^{\circ} \mathrm{C}$ \\
\hline 5. & Flash point & $>56^{\circ} \mathrm{C}$ \\
\hline 6. & Vapour pressure at $50^{\circ} \mathrm{C}$ & $2 \mathrm{kPa}$ \\
\hline 7. & Relative density at $15^{\circ} \mathrm{C}$ & $0.86 \mathrm{~g} / \mathrm{cm}^{3}$ \\
\hline 8. & Ignition temperature & $\geq 270^{\circ} \mathrm{C}$ \\
\hline 9. & Kinematic viscosity & $6 \mathrm{~mm}^{2} / \mathrm{s}$ \\
\hline \multicolumn{3}{|c|}{ Unleaded petrol 95} \\
\hline No. & Data & Number \\
\hline 1. & Appearance & Yellow liquid \\
\hline 2. & Smell & Characteristic of petrol \\
\hline 3. & The $\mathrm{pH}$ value & not applicable \\
\hline 4. & Melting and boiling range & From $30^{\circ} \mathrm{C}$ to $210^{\circ} \mathrm{C}$ \\
\hline 5. & Flash point & $-51^{\circ} \mathrm{C}$ \\
\hline 6. & Vapour pressure at $50^{\circ} \mathrm{C}$ & $118,6 \mathrm{kPa}$ \\
\hline 7. & Relative density at $15^{\circ} \mathrm{C}$ & $0.720-0.775 \mathrm{~g} / \mathrm{cm}^{3}$ \\
\hline 8. & Ignition temperature & $\geq 340^{\circ} \mathrm{C}$ \\
\hline 9. & Ignition temperature & $6 \mathrm{~mm}^{2} / \mathrm{s}$ \\
\hline
\end{tabular}

\subsection{Methodology}

Aim of this study was to analysis the process of adsorption in time and presentation of down-stream regulation of this action. Experiment was simulating the real accident of oil release to environment.

Scaling was including four steps. Weight of component listed below had to be known. Before setting weight should weigh and recorded mass values:

1. bucket,

2. PET container,

3. $150 \mathrm{ml}$ of sorbate,

4. As a last we weight $50 \mathrm{~g}$ of sorbent - our object of research (SD 0,10g).

Bucket with sorbent was hung under arm of scales, next PET bucket with chosen oil was placed under previous bucket. Reaction time was counted from the moment of pouring sorbent into bucket with oil and weight changes were reported every 30 seconds.

Process of adsorption is terminated when scales do not register any changes in weight. Records included final time of adsorption, weight of sorbent after experiment and weight of remaining oil substance in PET bucket. Final data was 
obtained by subtracting the weight of crude sorbent from weight of the sorbent after the process.

\subsection{Research working place}

Main element of research working place was an electronic scale with standard deviation of 0,001 gram. Scale was permanently screwed to laboratory bench. On the scale there were fit two blades, each of $25 \mathrm{~cm}$ long, wherein one of them was located under the scales. Two of them were combined by means of threaded pins $\varnothing 5[\mathrm{~mm}]$. In the bottom part, under the scales, the cage was fixed to the blade by flexible metal hose. It applied a bucket (size: height $100[\mathrm{~mm}]$, diameter $55[\mathrm{~mm}]$ and aperture size $0,5[\mathrm{~mm}]$ ). Under bucket was located an open tray PET, which was set on regulated stand. Regulated stand was used to lift free surface liquid during its falling down. All of this is assembly under a fume cupboard.

Saturation ratio can be calculated from the formula:

$$
\operatorname{sorption}[S]=\frac{\text { mass }}{\text { mass }} \frac{\text { sorbate }\left[m_{t e}\right]}{\operatorname{sorbent}\left[m_{t}\right]}\left[\frac{g}{g}\right]
$$

where:

mass sorbent $[\mathrm{g}]$ = gross mass sorption system $[\mathrm{g}]$ - mass of clean sorbent $[\mathrm{g}]$ mass of bucket after sorption process[g].

The percentage of sorbent absorptiveness can be count to multiple S and $100 \%$

$$
S \%=S \cdot 100 \%
$$

value. (form. 2).

Conditions for the experiment were $18{ }^{\circ} \mathrm{C}$ and $101305 \mathrm{~Pa}$ of atmospheric pressure. In first part of experiment only one repeat has been carried out for each sample (D1 and C2) and as a sorbent Ekoterm Plus was used.

\section{RESULTS}

Analysis of D1 and C2 ability to adsorb Ekoterm Plus suggests higher rate of speed for sample $\mathrm{C} 2$. We hypothesize that the obtained differences are caused by physical properties of the sorbent i.e. number of smaller and bigger particles per volume unit. Chemical composition of these two samples is the same. In both cases, whole volume of sorbat took part in process of adsorption. This means that Van der Waals forces between molecules of sorbent and sorbat are stronger than gravity. The level of sorbent D1 and C2 saturation, based on from Fig. 2 was 1.05 and 1.00 , respectively. 
Ability to suck the sorbat counted in percentage remain $105.43 \%$ and $100.42 \%$ from D1 and C2, respectively.

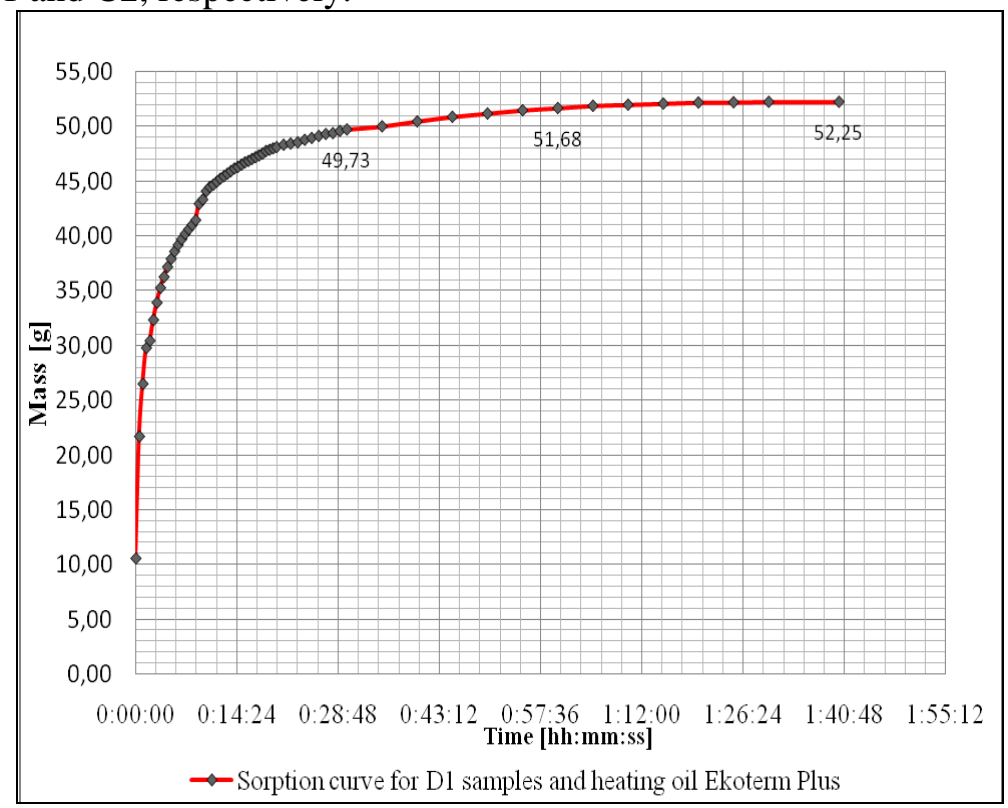

Fig. 2. Graph of sorption in time D1 sorbent and Ekoterm Plus oil term

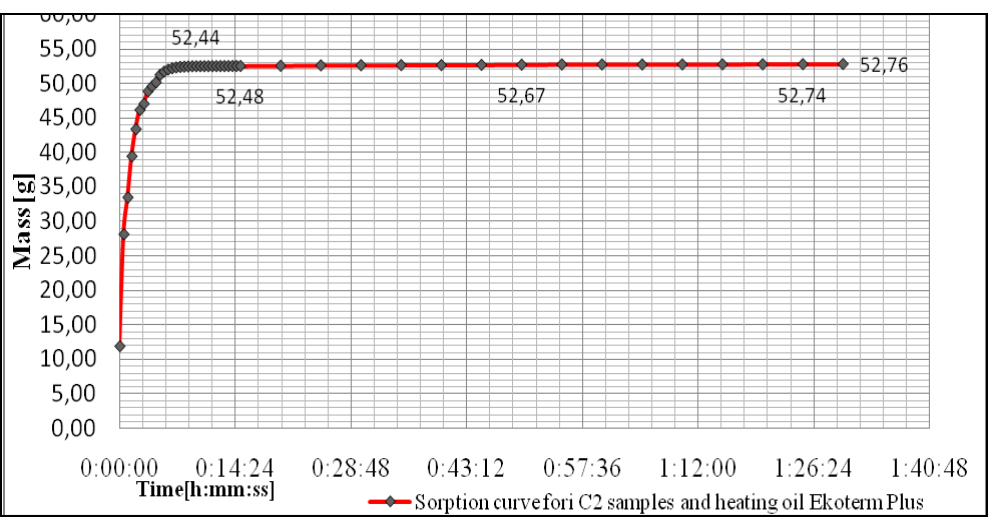

Fig. 3. Graph of sorption in time C2 sorbent and Ekoterm Plus oil term

In the second part of the research a different sorbat was used - Unleaded petrol 95. Analysing data from Fig. 3 and 4 we can observe that adsorption is spontaneous and occurs in relatively short time. And once again C2 sample is having higher rate of speed. Ability to suck the sorbat counted in percentage remains $98 \%$ and $94 \%$ from $\mathrm{D} 1$ and $\mathrm{C} 2$, respectively. 
Average difference in level of sucking properties in both experiments is around $4-5 \%$ and D1 has greater properties. We suggest that it is caused by different sized particles composition and improved number of macro-and - mesoporosity. Speed rate for C2 in both experiments is greater comparing to D1. Time of absorption for unleaded petrol 95 was shorter than for the other sorbat and was from 0 ' to 3 minutes.

Result can be expressed in time rate per volume unit. (Fig. 5.)

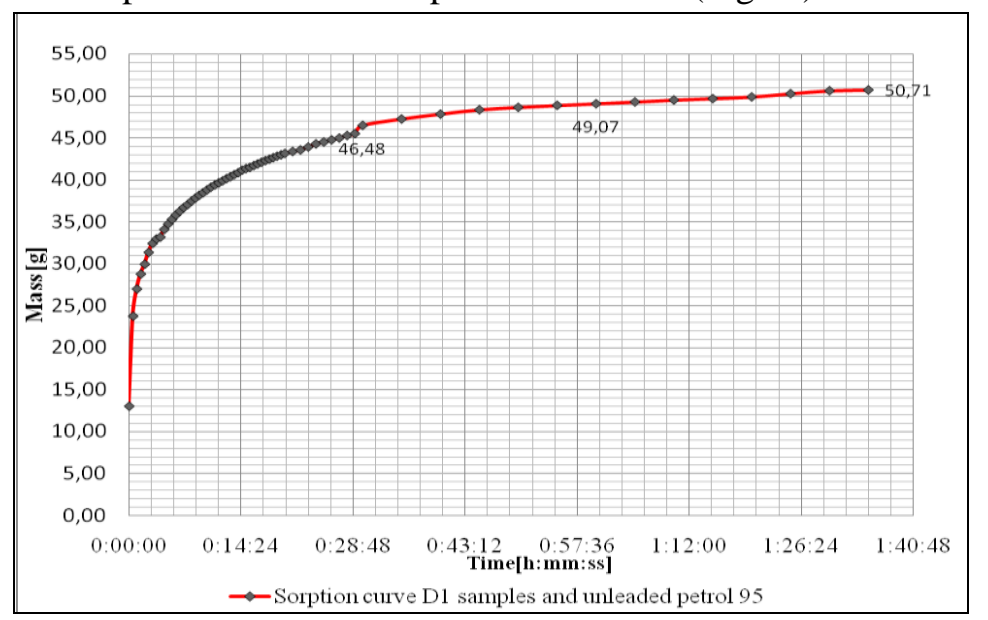

Fig. 4. Graph of sorption in time D1 sorbent and unleaded petrol 95 octane

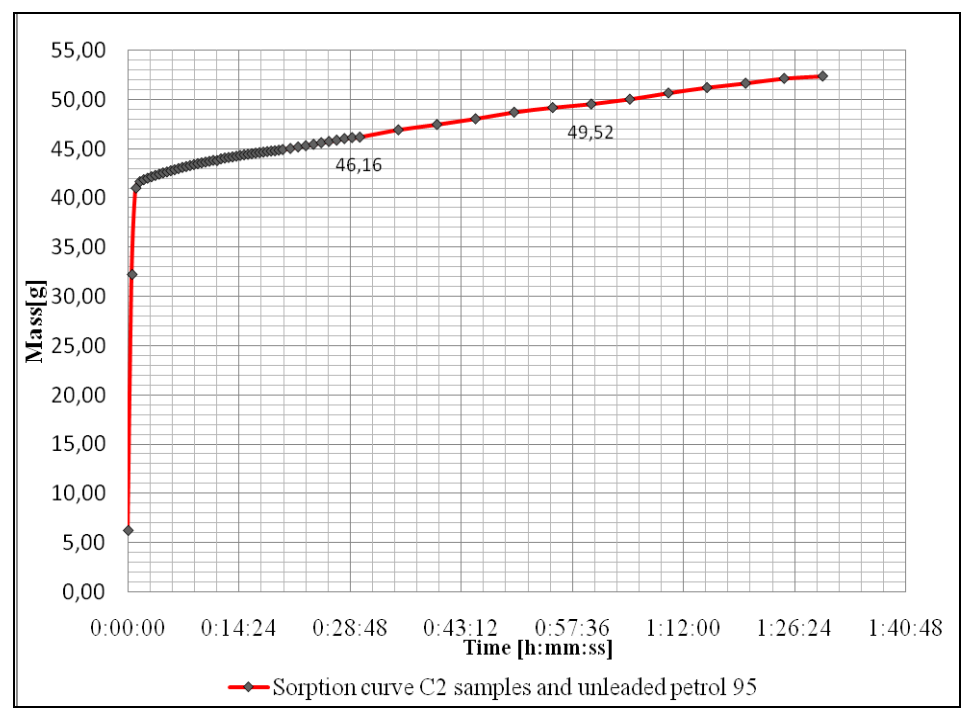

Fig. 5. Graph of sorption in time C2 sorbent and unleaded petrol 95 octane 


\section{DISSCUSSION AND CONCLUSION}

Data analysis suggests that better adsorption can be provided by mineral D1 sample. Greater adsorption was observed either in the first or in the second trial. These results are probably caused by the size of the particles and their content in the whole composition. D1 possesses a higher percentage of molecules in size above $1 \mathrm{~mm}$. It is connected with bigger number of macro- and mesoporous porosity, which is much lower in C2 sample.

$\mathrm{C} 2$ sample had a better result in time rate of adsorption. This spontaneous process took place in relatively short time and sorbent change in colour had been observed

This research suggests a higher efficiency of sorbent D1 in general, but if the time rate is important criteria $\mathrm{C} 2$ sorbent should be used. The result of this study will be helpful for chemical-ecological emergency team when an accident occurs. Sample D1 should be used in case, where pollution needs to be fully removed from environment and time limit doesn't play a role. This sorbent can be used to secure catch - basin grate. When the time is the limiting factor, for example in danger of fire, $\mathrm{C} 2$ sorbent will be a better choose.

Adsorbents which have been used in the study are less adsorptive than synthetic sorbents e.g. porous polyurethane foams [10], which have uptake capacity 20 . However their mass is higher than the mass of synthetic sorbents, and can be used in windy days. Sorbents from diatomite are in $100 \%$ natural and unlike the synthetic sorbents [11] do not produce harmful product of combustion. The adsorbents used in the study are ideal for use on impervious hardened surfaces. Additionally, speed rate of adsorption process is strictly dependent on density of our chosen sorbent.

\section{REFERENCES}

1. Harabasz L., Paprot L.: Problemy określania poziomu czyszczenia środowiska gruntowo - wodnego zanieczyszczonego produktami naftowymi na przyktadzie zakładu głównego PKN ORLEN S.A., Materiały konferencji naukowo - technicznej Inżynieria Ekologiczna Wysowa Zdrój 2000, Polskie Towarzystwo Inżynierii Ekologicnej Wysowa Zdrój 2000.

2. Renecki J.: Ratownictwo Chemiczno - Ekologiczne, Wydawnictwo Szkoły Aspirantów PSP, Poznań 1998.

3. Wilczyński T.: Sorbenty, podziat i kryteria doboru, Czytelnia Centrum Naukowo Badawczego Ochrony Przeciwpożarowej, Laboratorium Środków Gaśniczych i Sprzętu Podręcznego, Kwartalnik 2006/2.

4. Żabiński W.: Sorbenty Mineralne Polski - praca zbiorowa, red. AGH Uczelniane Wydawnictwa Naukowo - Dydaktyczne, Kraków 2008. 
5. Rakowska B.: Okrzemki - organizmy, które odniosty sukces, Kosmos Problemy Nauk Biologicznych, Polskie Towarzystwo Przyrodników im. Kopernika, Tom 52, Numer 2 - 3 (259 - 260).

6. Sylwester M, Kukuła M.: Sprawozdanie z I etapu opracowania na temat: „Określanie zastosowania diatomitów $w$ gospodarce narodowej $w$ oparciu o wystęujace badania w krajowych jednostkach badawczych oraz wybranie zaproponowanie badań aplikacyjnych”, Archiwum „Chemkop”, Kraków 1974.

7. Janas S., Karpisz S.: Korekcja sity wyporu w pomiarach masy, RADWAG Wagi Elektroniczne, Radom kwiecien 2012.

8. Karta Charakterystyki, Olej napędowy grzewczy - Ekoterm Plus, PKN Orlen S.A. 2011.

9. Karta Charakterystyki, Benzyny silnikowe bezolowiowe ES 95, ES 95A, ES 95AE, ES 95E, SUPER PLUS 98E, SUPER PLUS 98AE, VERVA 98, PKN Orlen S.A. 2011.

10. Atta A. M., Brostow W., Datashvili T., El-ghazawy R., Lobland H.E., Hasan Abdul-raheim M., Jose M. Perez Porous polyurethane foams based on recycled poly(ethylene terephthalate) for oil sorption, Research article SCI 2012.

11. Kowarska B., Baron J., Kandefer S., Żukowski W.: Spent Bentonite Sorbent Cleaning Process, Czasopismo Techniczne Technical Transactions Environmental Engeineering, 1-ś/2012.

\section{BADANIE PROCESU SORPCJI SKAŻEŃ ŚRODOWISKA SUBSTANCJAMI ROPOPOCHODNYMI Z WYKORZYSTANIEM SORBENTÓW MINERALNYCH}

\section{Streszczenie}

Przeprowadzono badania nad sorbentami pochodzenia okrzemkowego diatomitowego, stosowanymi do usuwania substancji niebezpiecznych, przy awaryjnych wyciekach. W badaniach zastosowano dwa rodzaje sorbentów dostępnych na rynku, różniących się gęstością nasypową i składem granulometrycznym. Scharakteryzowano diatomity pod względem mineralogicznym, sorpcyjnym i występowania geologicznego w Polsce. Jako sorbatów użyto oleju opałowego Ekoterm Plus i benzyny bezołowiowej $95 \mathrm{z}$ rafinerii PKN Orlen S.A. Podczas badań wykazano, że sorbenty o niższym składzie granulometryczym i większej gęstości nasypowej, wykazują większe właściwości sorpcyjne. Zarówno w pierwszej części jak i drugiej części badania, najszybciej chłonącym sorbentem okazał się C2, natomiast bardziej chłonnym (pod względem objętościowym) okazał się sorbent D1. Diatomity są dobrymi sorbentami pochodzenia organicznego, które spełniają oczekiwania pod względem sorpcyjnym. Swoje pochodzenie zawdzięczają mikronowym obumarłym komórkom glonowym. Ich atutem 
RESEARCH ON USING MINERAL SORBENTS FOR A SORPTION PROCESS IN THE ENVIRONMENT CONTAMINATED WITH PETROLEUM SUBSTANCES

jest wielofunkcyjność zastosowania zarówno w ochronie środowiska, rolnictwie czy też przemyśle ciężkim.

Słowa kluczowe: sorbenty, sorbenty mineralne, substancje ropopochodne

Editor received the manuscript: 16.04 .2013 